\title{
Hair mercury level of coastal communities in Malaysia: a linkage with fish consumption
}

\author{
Parvaneh Hajeb · Jinap Selamat • Ahmad Ismail • \\ Fatimah Abu Bakar · Jamilah Bakar • \\ Hanifah Nuryani Lioe
}

Received: 25 November 2007 / Revised: 15 February 2008 / Accepted: 21 February 2008 / Published online: 26 March 2008

(C) Springer-Verlag 2008

\begin{abstract}
Hair mercury level was assessed in four coastal communities in Malaysia with relation to fish consumption between gender, age, and rural and urban area. Mercury level was found at a range of $0.01-21.00(\mu \mathrm{g} / \mathrm{g}$ dry $w \mathrm{t})$. The average mercury levels were $13.69,10.85,9.94$, and $6.78 \mu \mathrm{g} / \mathrm{g}$ dry wt for communities in Kedah, Terengganu, Johor, and Selangor, respectively. The same order was found for the average monthly fish consumption, that is $14,620 \pm 878,9,966 \pm 563,8,939 \pm 793$, and $8,169 \pm 658$ $\mathrm{g} / \mathrm{month}$ for communities in the four respective regions. A highly significant positive correlation between hair mercury concentration and fish consumption was observed in all communities. This gives an insight that fish consumption is a significant route of mercury exposure for the coastal communities. Females had higher hair mercury concentration than what males had. Mercury exposure of communities in rural area was higher when compared to that in urban. However, mercury level in all Malaysian communities studied was much lower than no observable adverse effect level (NOAEL) of WHO, that is $50 \mathrm{mg} / \mathrm{g}$ dry wt.
\end{abstract}

Keywords Fish consumption - Mercury exposure · Risk assessment $\cdot$ Hair mercury content .

Coastal communities

P. Hajeb · J. Selamat $(\bowtie) \cdot$ F. A. Bakar · J. Bakar · H. N. Lioe National Food Safety Research Center,

Faculty of Food Science and Technology,

Universiti Putra Malaysia, 43400 Serdang, Selangor, Malaysia

e-mail: jinap@food.upm.edu.my

A. Ismail

Department of Biology, Faculty of Science,

Universiti Putra Malaysia, 43400 Serdang, Selangor, Malaysia

\section{Introduction}

Mercury is ubiquitous in the environment. It can be released and mobilized through both natural processes and anthropogenic activities and concentrates in seawater [1, 2], air [1], fish [3-5], and human or animal tissue [6]. Natural processes of significant $\mathrm{Hg}$ emissions include out-gassing of the earth's mantle material, evasion from surface soils, water bodies, vegetation surfaces, wild fires, volcanic activities, and geothermal processes [7, 8]. For over 3,500 years, humans have used mercury for various applications. For example, in the form of cinnabar, $\mathrm{HgS}$, mercury was used as a red pigment in cosmetics and paint. Calomel, $\mathrm{Hg}_{2} \mathrm{Cl}_{2}$, was one of the ingredients in "teething powder" that prior to 1960 was used to prevent ache in the mouth of children having their first teeth [9]. Metallic mercury has been used in a variety of laboratory equipment such as thermometers, barometers, and diffusion pumps. Elemental mercury forms alloys, called amalgam, with, for example, gold and silver, and this has been used in tooth fillings since the early nineteenth century [10]. In the beginning of the last century, alkyl mercury compounds were introduced as agricultural fungicides [11]. This eventually led to numerous mercury poison disasters, the most serious disaster being in Iraq, in 1971-1972, where maybe as many as 40,000 people were poisoned, of which 500 died [12]. Although more knowledge of its toxicity is now available, mercury in different forms is today still used as constituent in tooth filling material, pesticides, preservatives, catalysts, lamps, and batteries [13].

It is known that human exposure to mercury is mainly through fish consumption. In water or soil, microorganisms can convert inorganic mercury into a more toxic organic form, methylmercury [14-18]. Methylmercury can accumulate in animal tissues and cause biomagnifications in the aquatic food chain. Its concentrations are the highest in top predatory 
species [19]. Therefore, fish-consuming populations are a high-risk group for methylmercury exposure [20, 21].

To assess human exposure to mercury, body fluids such as blood and urine or tissues such as hair and nail have been analyzed [22-25]. Hair is a suitable indicator for biomonitoring of human exposure to mercury that can reflect organ mercury levels as well as dietary intake [26]. It is also reported to be able to reflect the average methylmercury concentrations circulating in the blood $[27,28]$. The convenience of hair sampling and its storage give the advantage for monitoring and field studies. However, environmental mercury vapor may bind to the hair [29], while hair permanent treatments and hair coloring may affect the mercury concentration [30-32].

This study aims to assess mercury exposure through mercury measurement in the hair of adult population in four coastal regions, located in northeastern, western, and eastern coastlines of peninsular Malaysia. The influence of fish consumption, with considering the gender, age, rural, or urban factors, to the risk of mercury was evaluated.

\section{Materials and methods}

Study areas and population of study

The survey on fish consumption was conducted in four different coastal states of Malaysia; M1, Johor; M2, Terengganu; M3, Kedah; and M4, Selangor (Fig. 1). Sampling locations in each state were divided into two: urban and rural area. The respondents covered were the three main

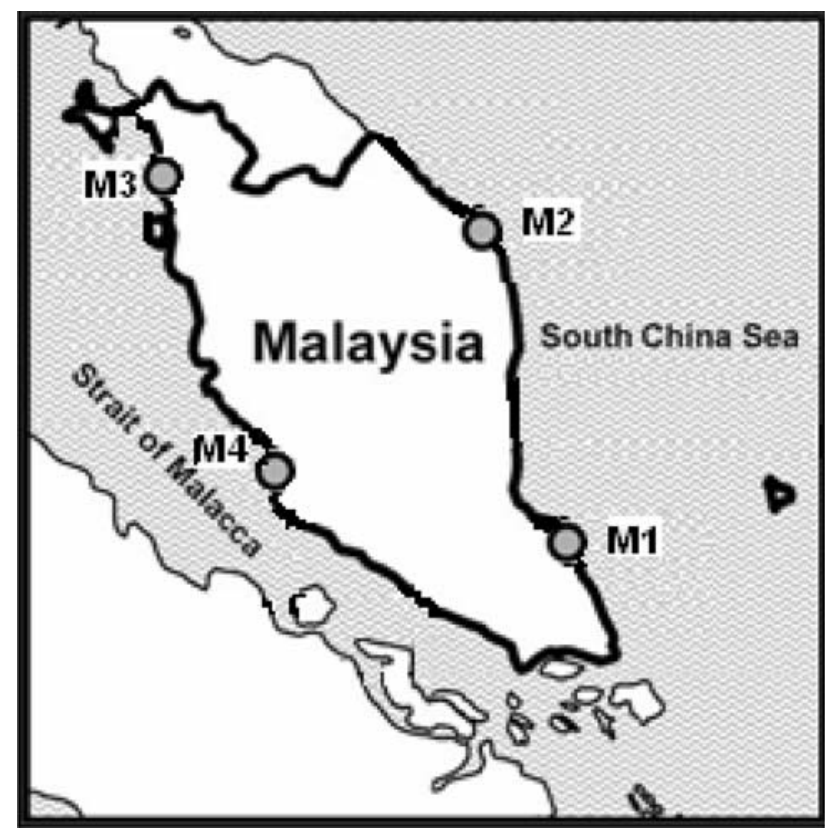

Fig. 1 Map of four coastal communities in Peninsular Malaysia races (Malay, Chinese, and Indian) living in Malaysia. A total of 800 adults ( 387 men, 413 women) aged from 18 to 80 years were interviewed to answer the fish consumption questionnaire. However, only 380 respondents (147 men and 233 women) committed to donate their hair sample.

Dietary intake was assessed using a food frequency questionnaire (FFQ) with 1-month recall. The questionnaires were developed based on a review of the literature and other related studies [32, 33]. The questionnaires were pilot-tested on community representatives and were found to be culturally acceptable. The FFQ was divided into the three food categories (canned fish, local fish dishes, and fish snacks). The participants were first asked to identify whether the item was consumed and whether it was cooked at home or eaten outside. To facilitate the recall, a booklet of fish and food picture with serving sizes and local and English names were shown to the respondents.

\section{Hair sample collection and preparation}

Hair samples were collected from donors by cutting strands of hair close to the scalp in the occipital region, using a clean stainless steel scissor. The hair samples were then kept in clean polyethylene bags and transported to the laboratory. The samples were cut into pieces $(4-6 \mathrm{~mm})$, washed three times with nonionic detergent (1\% v/v Triton X-100), and rinsed three times with deionized water. After washing, the hair samples were dried in an electric oven at $60{ }^{\circ} \mathrm{C}$ and kept in polyethylene bags until used for mercury analysis [23].

Analytical procedures

Sample preparation and determination of mercury in hair followed the method by Akagi and others [22]. Hair samples $(10 \mathrm{mg})$ were digested through the addition of nitricperchloric and sulfuric acid solution and heated in a water bath at $90{ }^{\circ} \mathrm{C}$ for $30 \mathrm{~min}$. The digested sample was then cooled, diluted with deionized water, and filtered for mercury analysis. Mercury was determined in all the samples, using inductively coupled plasma atomic emission spectroscopy (ICP-AES) (Thermo Elemental, Iris advantage model), according to the manufacturer's instruction. The detection limit was $3 \mathrm{ng} / \mathrm{g}$. Mercury stock standard solution $(1,000 \mathrm{mg} / \mathrm{l})$ was prepared by dissolving $0.0677 \mathrm{~g}$ of $\mathrm{HgCl}_{2}$ in the $3 \% \mathrm{HCl}$ in a $100-\mathrm{ml}$ digestion flask. Analytical accuracy was tested using spiked samples and standard addition method. Ninety-six percent of recovery was obtained using this analytical procedure.

Statistical methods

Statistical analyses were performed with SPSS (version 12.0, SPSS Inc., Chicago, IL, USA) and Minitab (version 
14.12.0, (C) 1972-2004 Minitab Inc.) software. Relationships between mercury, and age and fish consumption were examined by Pearson's correlation coefficient, as well as by simple and multiple regression analyses. Sexual difference in concentrations of mercury in hair was tested by Student's $t$ test. ANOVA were used to test the difference between mercury levels in hair of donors residing in different locations. A $P$ value of less than 0.05 was considered as statistical significant.

\section{Results and discussion}

Regional and race differences in hair mercury levels

Table 1 shows demographic characteristics of hair donors. The hair donors were from urban and rural communities in four Malaysian coastline states. Therefore, there are totally eight communities assessed. Each community covers three major races: Malay, Chinese, and Indian.

Table 2 shows mercury concentration in human hair from the eight communities in the Peninsular Malaysia. Mercury concentration in hair of Malaysian ranged from

Table 1 Demographic characteristics of hair donors

\begin{tabular}{|c|c|c|c|}
\hline Characteristics & $\begin{array}{l}\text { Men } \\
(N=147)\end{array}$ & $\begin{array}{l}\text { Women } \\
(N=233)\end{array}$ & $\begin{array}{l}\text { Overall } \\
(N=380)\end{array}$ \\
\hline Age & $37.72 \pm 1.17$ & $38.90 \pm 0.89$ & $38.44 \pm 0.71$ \\
\hline \multicolumn{4}{|l|}{ State } \\
\hline Johor (M1) & 13.61 & 11.16 & 12.11 \\
\hline Terengganu (M2) & 27.89 & 39.05 & 34.73 \\
\hline Kedah (M3) & 36.05 & 42.91 & 40.26 \\
\hline Selangor (M4) & 22.44 & 6.86 & 13.16 \\
\hline \multicolumn{4}{|l|}{ Geographical location } \\
\hline Rural & 36.05 & 36.90 & 36.57 \\
\hline Urban & 63.94 & 63.09 & 63.42 \\
\hline \multicolumn{4}{|l|}{ Race } \\
\hline Malay & 85.03 & 92.27 & 89.47 \\
\hline Chinese & 10.20 & 5.15 & 6.57 \\
\hline Indian & 4.76 & 2.57 & 2.63 \\
\hline \multicolumn{4}{|l|}{ Education } \\
\hline None & 2.04 & 6.86 & 5 \\
\hline Primary school & 23.80 & 16.30 & 19.21 \\
\hline Secondary school & 52.38 & 51.93 & 52.10 \\
\hline Vocational school & 6.12 & 2.14 & 3.68 \\
\hline College/university & 15.64 & 22.47 & 20 \\
\hline \multicolumn{4}{|l|}{ Income } \\
\hline$<500$ & 78.23 & 82.40 & 80.78 \\
\hline $500-1,000$ & 10.88 & 16.73 & 14.47 \\
\hline$>1,000$ & 10.88 & 0.85 & 4.73 \\
\hline
\end{tabular}

All values (except the age) are expressed in percentage
Table 2 Hair mercury concentration in populations from four states in Peninsular Malaysia

\begin{tabular}{lccc}
\hline Population group & \multicolumn{3}{c}{ Mercury concentration $(\mu \mathrm{g} / \mathrm{g}$ dry wt) } \\
\cline { 2 - 4 } & Mean & SE & Range \\
\hline Johor (M1) & 9.94 & 0.78 & $0.60-19.76$ \\
Urban & 9.84 & 0.88 & $0.60-19.76$ \\
Rural & 10.31 & 1.66 & $3.80-17.40$ \\
Terengganu (M2) & 10.85 & 0.49 & $0.10-19.90$ \\
Urban & 9.82 & 0.54 & $0.98-19.90$ \\
Rural & 12.47 & 0.91 & $0.10-19.75$ \\
M3 Kedah (M3) & 13.69 & 0.48 & $0.05-21.00$ \\
Urban & 11.41 & 0.74 & $0.05-20.50$ \\
Rural & 15.99 & 0.52 & $3.36-21.00$ \\
Selangor (M4) & 6.78 & 0.94 & $0.02-19.74$ \\
Urban & 5.34 & 0.28 & $0.02-17.29$ \\
Rural & 8.22 & 0.87 & $0.38-19.74$ \\
\hline
\end{tabular}

0.02 to $21.00 \mu \mathrm{g} / \mathrm{g}$ dry wt. There was a significant difference between mercury concentration of communities in rural and urban area $(P<0.001)$. The mercury levels were higher in rural communities. Hair mercury concentrations between communities in the four states were significantly different $(P<0.001)$. The value was highest in communities of Kedah and lowest in communities of Selanogor, while those between donors from Johor and Terengganu were not significantly different $(P>0.001)$. However, there was no significant difference between hair mercury contents of the three studied races $(P>0.001)$.

Age- and gender-dependent accumulation of mercury in humans

In communities of Selangor, Kedah, and Terengganu, female donors showed significantly higher mercury concentration in hair than what the male donors showed $(P<0.05)$. Table 3 shows the correlation between mercury concentrations and age of donors. The significant correlation was only found slightly between hair mercury content and age of males from Terengganu $\left(R^{2}=0.283\right)$.

Effect of fish consumption on hair mercury level in hair

Fish consumption is one of the main sources of mercury intake in humans [31, 34-38]. Fish consumption (g/month) has been calculated in hair donors to determine the mercury exposure through fish consumption. Questionnaire results showed that Malaysian people, on average, consumed $11,442 \mathrm{~g}$ fish/month (Table 4). In the three studied states, communities in rural area consumed significantly higher amounts of fish when compared to those in urban area. 
Table 3 Pearson correlation coefficient between hair mercury concentrations and age of respondents in four coastal states in Malaysia

\begin{tabular}{lrrl}
\hline Group & \multicolumn{1}{l}{$N$} & \multicolumn{1}{l}{$R^{2}$} \\
\hline All & 380 & 0.103 & 0.045 \\
Male & 234 & 0.004 & 0.949 \\
Female & 146 & 0.203 & 0.014 \\
Selangor & 44 & -0.257 & 0.093 \\
Male & 37 & -0.134 & 0.428 \\
Female & 7 & -0.711 & 0.073 \\
Kedah & 158 & 0.135 & 0.092 \\
Male & 79 & 0.113 & 0.321 \\
Female & 79 & 0.063 & 0.580 \\
Terengganu & 132 & -0.018 & 0.834 \\
Male & 81 & 0.283 & 0.043 \\
Female & 51 & -0.161 & 0.150 \\
Johor & 46 & 0.132 & 0.382 \\
Male & 37 & 0.108 & 0.525 \\
Female & 9 & 0.233 & 0.546 \\
\hline
\end{tabular}

Table 4 Pearson correlation coefficient between hair mercury concentrations and fish consumption of population in four coastal states in Malaysia

\begin{tabular}{lrrrl}
\hline Population group & \multicolumn{4}{l}{ Fish consumption (g/month) } \\
\cline { 2 - 5 } & \multicolumn{1}{l}{ Mean } & \multicolumn{1}{c}{ SE } & \multicolumn{1}{l}{$R^{2}$} & $P$ \\
\hline Johor (M1) & 8,939 & 793 & 0.902 & 0.000 \\
Urban & 9,084 & 956 & 0.909 & 0.000 \\
Rural & 8,343 & 1,051 & 0.994 & 0.000 \\
Terengganu (M2) & 9,966 & 563 & 0.867 & 0.000 \\
Urban & 8,653 & 618 & 0.810 & 0.000 \\
Rural & 12,051 & 1,019 & 0.906 & 0.000 \\
Kedah (M3) & 14,620 & 878 & 0.723 & 0.000 \\
Urban & 12,181 & 1,236 & 0.750 & 0.000 \\
Rural & 17,060 & 1,194 & 0.665 & 0.000 \\
Selangor (M4) & 8,169 & 1,031 & 0.875 & 0.000 \\
Urban & 7,076 & 1,076 & 0.904 & 0.002 \\
Rural & 9,263 & 1,151 & 0.885 & 0.002 \\
\hline
\end{tabular}

Donors living in Kedah state showed the highest fish consumption of $14,620 \mathrm{~g}$ fish/month. There was no gender difference in terms of consumption $(P>0.005)$. A highly significant positive correlation was found between hair mercury concentration and with consumption in all the studied populations (Figs. 2, 3).

Comparison of hair mercury levels to other Asian countries

To understand the mercury contamination status in Malaysia, concentrations of hair mercury in this study were compared

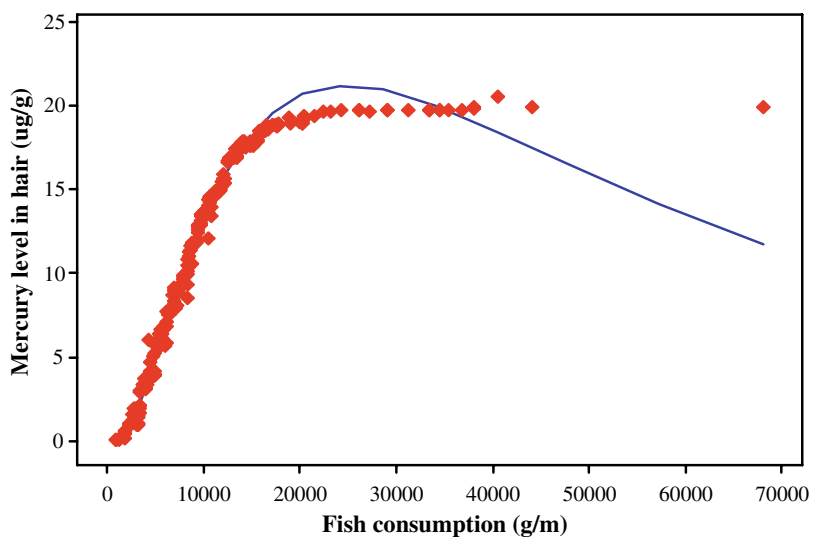

Fig. 2 Correlation between hair mercury level ( $\mu \mathrm{g} / \mathrm{g}$ dry wt) and fish consumption $(\mathrm{g} / \mathrm{month})$ in Malaysian women $\left(S=0.07358 ; R^{2}=97.6 \%\right)$

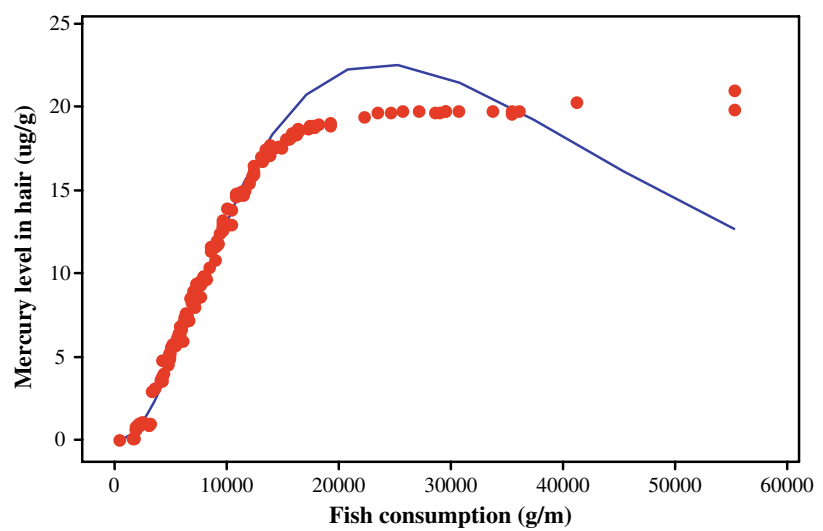

Fig. 3 Correlation between hair mercury level ( $\mu \mathrm{g} / \mathrm{g}$ dry wt) and fish consumption (g/month) in Malaysian men $\left(S=0.1173 ; R^{2}=94.6 \%\right)$

with those in recent studies from other Asian countries (Table 5). Concentration of hair mercury in Malaysian communities studied was higher than that in previous research done by Sarmani and Alakili [39]. It can be explained by the different geographical and environmental conditions. The highest mercury levels in the present study, which were found in rural area or fishery villages, were comparable to those from Japan (Wakayama, Kumamoto) and Indonesia (Medan) $[31,40]$. However, the highest mercury level in the Malaysian communities was far below that reported for Cambodia, Japan (Tokushima, Minamata, Chiba), and China (Harbin) [24, 31, 40, 41].

World Health Organization (WHO) reported that no health effect was observed in donors with the hair mercury level below $50 \mathrm{mg} / \mathrm{g}$ dry wt, based on the neurotoxicity data in Japan and Iraq [42, 43]. According to the report, mercury in all hair donors either from rural or from urban area in four states in Peninsular Malaysia was well below NOAEL of WHO. It was known that the estimation level of mercury in maternal hair that reflects no appreciable adverse effects 
Table 5 Comparison of hair mercury level ( $\mu \mathrm{g} / \mathrm{g}$ dry wt) of Malaysian communities with those in other Asian countries

\begin{tabular}{|c|c|c|c|c|c|}
\hline Location & Mean & Median & Range & Remark & References \\
\hline Malaysia & 11.45 & 12.00 & $0.01-21.00$ & Rural and urban area & Current research \\
\hline Kuala Lumpur, Malaysia & - & 3.38 & $0.59-18.37$ & Urban area & Sarmani and Alakili 2004 [39] \\
\hline Libya & - & 0.81 & $0-3.6$ & - & Sarmani and Alakili 2004 [39] \\
\hline Jordan & - & 0.69 & $0.32-4.0$ & - & Sarmani and Alakili 2004 [39] \\
\hline Cambodia & 3.1 & - & $0.54-190$ & - & Agusa et al. 2005 [41] \\
\hline Phnom Penh, Cambodia & & - & $5.2-58$ & - & Agusa et al. 2007 [24] \\
\hline Japan & 1.51 & - & - & Female & Ohno et al. 2007 [25] \\
\hline Minamata, Japan & - & - & $2.46-705$ & Patients of Minamata disease & Harada 1995 [45] \\
\hline Shiranui Bay, Japan & 5.0 & - & - & Male & Harada et al. 1998 [36] \\
\hline Shiranui Bay, Japan & 2.1 & - & - & Female & Harada et al. 1998 [36] \\
\hline Minamata, Japan & 1.76 & - & $0.09-10.56$ & - & Yasutake et al. 2003 [31] \\
\hline Kumamoto, Japan & 1.57 & - & $0.14-19.18$ & - & Yasutake et al. 2003 [31] \\
\hline Tottori, Japan & 2.04 & - & $0.00-12.52$ & - & Yasutake et al. 2003 [31] \\
\hline Wakayama, Japan & 2.04 & - & $0.00-20.66$ & - & Yasutake et al. 2003 [31] \\
\hline Chiba, Japan & 3.37 & - & $0.14-26.76$ & - & Yasutake et al. 2003 [31] \\
\hline Tokyo and surrounding areas, Japan & 2.98 & - & - & Male & Nakagawa 1995 [44] \\
\hline Tokyo and surrounding areas, Japan & 2.02 & - & - & Female & Nakagawa 1995 [44] \\
\hline Tokushima, Japan & 4.62 & - & $0.626-24.6$ & - & Feng et al. 1998 [40] \\
\hline Harbin, China & 1.69 & - & $0.112-36.4$ & - & Feng et al. 1998 [40] \\
\hline Medan, Indonesia & 3.13 & - & $0.203-19.9$ & - & Feng et al. 1998 [40] \\
\hline Hong Kong, China & 3.33 & - & - & Fertile male & Dickman et al. 1998 [46] \\
\hline Hong Kong, China & 4.23 & - & - & Sub-fertile male & Dickman et al. 1998 [46] \\
\hline Seoul, Korea & 1.7 & - & - & Male & Lee et al. 2000 [52] \\
\hline Seoul, Korea & 1.1 & - & - & Female & Lee et al. 2000 [52] \\
\hline Diwalwal, Philippines & - & 2.77 & - & Downstream of gold mine & Drasch et al. 2001 [53] \\
\hline Diwalwal, Philippines & - & 1.71 & - & Gold mine, nonoccupation & Drasch et al. 2001 [53] \\
\hline Diwalwal, Philippines & - & 3.62 & - & Gold mine, occupation & Drasch et al. 2001 [53] \\
\hline Diwalwal, Philippines & - & 2.65 & - & Control & Drasch et al. 2001 [53] \\
\hline Doha, Kuwait & 4.181 & - & - & Fisherman & Al-Majed and Preston 2000 [37] \\
\hline Bangladesh & 0.44 & - & $0.02-0.95$ & Fish consumption & Holsbeek et al. 1996 [35] \\
\hline Mansoura, Egypt & 0.23 & - & $0.11-0.410 .23$ & Urban area & Mortada et al. 2002 [23] \\
\hline
\end{tabular}

in the offspring is $14 \mu \mathrm{g} / \mathrm{g}$ dry wt of hair mercury [43]. Moreover, Harada et al. [36] reported that the upper limit of a normal hair mercury level is $10 \mu \mathrm{g} / \mathrm{g}$ dry wt. However, Grandjean et al. [26] showed that mercury-related neuropsychological dysfunctions were present in children even with mercury levels below $10 \mu \mathrm{g} / \mathrm{g}$ dry wt in maternal head hair in the Tapajos River basin, Brazil, and in the Faroe Islands, Denmark. In this study, $44 \%$ of respondents had more than $14 \mu \mathrm{g} / \mathrm{g}$ dry wt of hair mercury, and $61 \%$ had more than $10 \mu \mathrm{g} / \mathrm{g}$ dry wt of hair mercury. If the high hair mercury levels are associated with the body burden and are not due to external deposition onto the surface of hair, certain populations in Malaysia may have risk of neurotoxic effects due to the elevated mercury exposure.

This study also showed the significant difference between hair mercury levels of different gender, as reported above. This is in accordance with other researchers results. Batista et al. [34] reported that women exhibited higher mercury level in their hair than what men exhibited, whereas mercury concentration in the hair of males was higher than that of females in other studies [31, 44-46]. However, some studies showed that gender is unlikely to be an important factor determining mercury accumulation in hair [23, 31, 38, 41, 47].

Fish consumption was the most significant predictor of mercury in the population studied. Our results support the findings of earlier studies, indicating that the concentration of mercury found in hair of adult respondents with no occupational exposure is mainly dependent on dietary intake [35, 48-53]. Mercury exposure was higher in rural area compared to that in urban area. These could be explained by the difference between diet, community life style, and 
environmental factors. In the urban communities, the typical monthly fish consumption consisted of canned tuna, sardine, anchovies and salmon, fish ball and nuggets, and fresh fishes found in the local markets; while in rural or fishing villages, peoples consumed locally caught fresh fish. The number of fish consumption in rural area was generally higher than that in urban area.

The fact that the concentration of hair mercury in Malaysian communities studied here was higher than that of previous research done by Sarmani and Alakili (2004) [39] is due to the different geographical and environmental conditions. The relatively high mercury level found in hair of Malaysian communities suggests an existence of mercury risk in Malaysia.

\section{Discussion}

Fish consumption was the most significant predictor of mercury in the coastal communities studied. Mercury exposure was higher in rural area when compared to that in urban area. This could be explained by higher fish consumption of communities in rural area or fishery villages. In all the four coastal states, female donors showed higher mercury concentration in hair than that showed by males. Mercury level in all Malaysian communities studied did not exceed NOAEL of WHO. However, the level remains relatively high and gives a risk alert of the mercury exposure.

Acknowledgments We thank The Ministry of Science, Technology and Innovation of Malaysia, which has sponsored this research under EScience Fund Project No. UPM0002449.

\section{References}

1. Boening DW (2000) Ecological effects, transport, and fate of mercury: a general review. Chemosphere 40:1335-1351

2. Ferrara R, Mazzolai B, Lanzillotta E, Nucaro E, Pirrone N (2000) Volcanoes as emission sources of atmospheric mercury in the Mediterranean basin. Sci Total Environ 259:115-121

3. Adams DH, Tremain DM (2000) Association of large juvenile red drum, Sciaenops ocellatus, with an estuarine creek on the Atlantic coast of Florida. Environ Biol Fishes 58(2):183-194

4. Bloom NS (1992) On the chemical form of mercury in edible fish and marine invertebrate tissue. Can J Fish Aquat Sci 49:1010-1017

5. Grieb TM, Driscoll CT, Gloss SP, Schofield CL, Bowie GL, Porcella DB (1990) Factors affecting mercury accumulation in fish in the upper Michigan peninsula. Environ Toxicol Chem 9:919-930

6. Choy CMY, Lam CWK, Cheung LTF, Briton-Jones CM, Haines CJ (2002) Infertility, blood mercury concentrations and dietary seafood consumption: a case-control study. BJOG 109(10):11211125

7. Gustin MS, Lindberg SE, Austin K, Coolbaugh M, Vette A, Zhang $\mathrm{H}$ (2000) Assessing the contribution of natural sources to regional atmospheric mercury budgets. Sci Total Environ 259:61-71

8. Schroeder WH, Munthe J (1998) Atmospheric mercury-an overview. Atmos Environ 32(5):809-822
9. Herrstrom P, Bratt I, Holmen A, Hogstedt B (2003) Micronuclei in lymphocyte subsets in relation to plasma mercury, dental amalgam and acrylate-containing tooth fillings. Sci Total Environ 309:253255

10. Halbacha S, Vogtb S, Kohlerc W, Felgenhauerd N, Welzle G, Kremersb L, Zilkerd T, Melchartc D (2008) Blood and urine mercury levels in adult amalgam patients of a randomized controlled trial: interaction of $\mathrm{Hg}$ species in erythrocytes. Environ Res [1 Sept 2007, Epub ahead of print]

11. Chatterjee S, Pillai A, Gupta VK (2002) Spectrophotometric determination of mercury in environmental sample and fungicides based on its complex with $o$-carboxy phenyl diazoamino $p$-azobenzene. Talanta 57:461-465

12. Bakir F, Damluji SF, Amin-Zaki L, Khalidi A, al-Rawi NY, Tikriti S, Dahahir HI, Clarkson TW, Smith JC, Doherty RA (1973) Methylmercury poisoning in Iraq. Science 181:230-241

13. Clarkson TW (2002) The three modern faces of mercury. Environ Health Perspect 110:11-23

14. Aschner M (2001) Mercury toxicity. J Pediatr 138:450-451

15. Axtell CD, Cox C, Myers GJ, Davidson PW, Choi AL, Cernichiari E, Sloane-Reeves J, Shamlaye CF, Clarkson TW (2001) Association between methylmercury exposure from fish consumption and child development at five and a half years of age in the Seychelles Child Development Study: an evaluation of nonlinear relationships. Environ Res 84:71-80

16. Castoldi AF, Coccini T, Ceccatelli S, Manzo L (2001) Neurotoxicity and molecular effects of methylmercury. Brain Res Bull 55:197-203

17. Frankish H (2001) US centers to study relation between environment and developmental disorders. Lancet 358:1518

18. Mendola P, Selevan SG, Gutter S, Rice D (2002) Environmental factors associated with a spectrum of neurodevelopmental deficits. Ment Retard Dev Disabil Res Rev 8:188

19. De Souza Lima AP, Sarkis Muller RC, De Souza Sarkis JE, Nahum Alves C, Da Silva Bentes MH, Brabo E (2000) Mercury contamination in fish from Santarem, Para, Brazil. Environ Res $83: 117-122$

20. Choi BH (1989) The effects of methylmercury on the developing brain. Prog Neurobiol 32:447-470

21. IPCS (International Programme on Chemical Safety) (1990) Methylmercury (Environmental Health Criteria 101). World Health Organization, Geneva

22. Akagi H, Malm O, Branches FJP, Kinjo Y, Kashima Y, Guimaraes JRD, Oliveira RB, Haraguchi K, Pfeiffer WC, Takizawa Y, Kato $H$ (1995) Human exposure to mercury due to gold mining in the Tapajos river basin, Amazon, Brazil: speciation of mercury in human hair, blood and urine. Water Air Soil Pollut 80:85

23. Mortada WI, Sobh MA, El-Defrawy MM, Farahat SE (2002) Reference intervals of cadmium, lead, and mercury in blood, urine, hair, and nails among residents in Mansoura city, Nile Delta, Egypt. Environ Res 90:104-110

24. Agusa T, Kunito T, Iwata H, Monirith I, Chamnan C, Seang Tana T, Subramanian A, Tanabe S (2007) Mercury in hair and blood from residents of Phnom Penh (Cambodia) and possible effect on serum hormone levels. Chemosphere 68:590-596

25. Ohno T, Sakamotob M, Kurosawaa T, Dakeishia M, Iwataa T, Murata K (2007) Total mercury levels in hair, toenail, and urine among women free from occupational exposure and their relations to renal tubular function. Environ Res 103:191-197

26. Grandjean P, Weihe P, Nielsen JB (1994) Methylmercury: significance of intrauterine and postnatal exposures. Clin Chem 40:1395-1400

27. Cernichiari E, Toribara TY, Liang L, Marsh DO, Berlin M, Myers GJ, Cox C, Shamlaye CF, Choisy O, Davidson PW (1995) The biological monitoring of mercury in the Seychelles study. Neurotoxicology 16:613-628 
28. Yamaguchi S, Matsumoto H, Kaku S, Tateishi M, Shiramizu M (1975) Factors affecting the amount of mercury in human scalp hair. Am J Public Health 65:484-488

29. Yamamoto R, Suzuki T (1978) Effects of artificial hair-waving on hair mercury values. Int Arch Occup Environ Health 42:1-9

30. Grandjean P, Jirgensen PJ, Weihe P (2002) Validity of mercury exposure biomarkers. In: Wilson SH, Suk WA (eds) Biomarkers of environmentally associated disease. CRC Press/Lewis, Boca Raton, pp 235-247

31. Yasutake A, Matsumoto M, Yamaguchi M, Hachiya N (2003) Current hair mercury levels in Japanese: survey in five districts. Tohoku J Exp Med 199:161-169

32. Tran NI, Barraj L, Smith K, Javier A, Burke TA (2004) Combining food frequency and survey data to quantify long-term dietary exposure: a methylmercury case study. Risk Anal 24(1):19-30

33. McNutt S, Zimmerman TP, Hull S (2008). Development of food composition databases for food frequency questionnaires (FFQ). $J$ Food Compost Anal (in press)

34. Batista J, Schuhmacher M, Domingo JL, Corbella J (1996) Mercury in hair for a child population from Tarragona Province, Spain. Sci Total Environ 193:143-148

35. Holsbeek L, Das HK, Joiris CR (1996) Mercury in human hair and relation to fish consumption in Bangladesh. Sci Total Environ 186:181-188

36. Harada M, Nakanishi J, Konuma S, Ohno K, Kimura T, Yamaguchi H, Tsuruta K, Kizaki T, Ookawara T, Ohno H (1998) The present mercury contents of scalp hair and clinical symptoms in inhabitants of the Minamata area. Environ Res 77:160-164

37. Al-Majed NB, Preston MR (2000) Factors influencing the total mercury and methyl mercury in the hair of the fishermen of $\mathrm{Ku}$ wait. Environ Pollut 109:239-250

38. Olivero J, Johnson B, Arguello E (2002) Human exposure to mercury in San Jorge river basin, Colombia (South America). Sci Total Environ 289:41-47

39. Sarmani SB, Alakili I (2004) Application of neutron activation analysis for mercury species determination in scalp hair samples from Malaysia, Libya and Jordan. J Radioanal Nucl Chem 262:43-48

40. Feng Q, Suzuki Y, Hisashige A (1998) Hair mercury levels of residents in China, Indonesia, and Japan. Arch Environ Health 53:36-43

41. Agusa T, Kunito T, Iwata H, Monirith I, Chamnan C, Seang Tana $\mathrm{T}$, Subramanian A, Tanabe S (2005) Mercury contamination in human hair and fish from Cambodia: levels, specific accumulation and risk assessment. Environ Pollut 134:79-86

42. Harada M (1995) Minamata disease: methylmercury poisoning in Japan caused by environmental pollution. Crit Rev Toxicol 125:1-24

43. FAO/WHO (2006) Summary and conclusions of the sixty-seventh meeting of the Joint FAO/WHO Expert Committee on Food Additives (JECFA), 20-29 June 2006. JECFA/61/SC 2006. http:// www.chem.unep.ch/mercury/Report/JECFA-PTWI.htm. Accessed October 2007

44. Nakagawa R (1995) Concentration of mercury in hair of Japanese people. Chemosphere 30:127-133

45. Saeki K, Fujimoto M, Kolinjim D, Tatsukawa R (1996) Mercury concentrations in hair from populations in Wau-Bulolo area, Papua New Guinea. Arch Environ Contam Toxicol 30:412-417

46. Dickman MD, Leung CKM, Leong MKH (1998) Hong Kong male subfertility links to mercury in human hair and fish. Sci Total Environ 214:165-174

47. Kosatsky T, Przybysz R, Armstrong B (2000) Mercury exposure in Montrealers who eat St. Lawrence River sportfish. Environ Res 84:36-43

48. Johnsson C, Sallsten G, Schutz A, Sjors A, Barregard L (2004) Hair mercury levels versus freshwater fish consumption in household members of Swedish angling societies. Environ Res 96:257-263

49. McDowell MA, Dillon CF, Osterloh J, Bolger PM, Pellizzari E, Fernando R (2004) Hair mercury levels in US children and women of childbearing age: reference range data from NHANES 1999 2000, Environ. Health Perspect 112:1165-1171

50. Morrissette J, Takser L, St-Amour G, Smargiassi A, Lafond J, Mergler D (2004) Temporal variation of blood and hair mercury levels in pregnancy in relation to fish consumption history in a population living along the St. Lawrence River. Environ Res 95:363-374

51. Bjornberg KA, Vahter M, Grawe KP, Berglund M (2005) Methyl mercury exposure in Swedish women with high fish consumption. Sci Total Environ 341:45-52

52. Lee WC, Lee MJ, Lee SM, Kim JS, Bae CS, Park TK (2000) An observation on the mercury contents of scalp hair in the urban residents of South Korea. Environ Toxicol Pharmacol 8(4):275-278

53. Drascha G, Bose-O'Reilly S, Beinhoff C, Roider G, Maydl S (2001) The Mt. Diwata study on the Philippines 1999 assessing mercury intoxication of the population by small scale gold mining. Sci Total Environ 267:151-168 